ЦІН ШЕНЬ

\title{
ФОРМУВАННЯ ДУХОВНО-МОРАЛЬНОЇ КУЛЬТУРИ МАЙБУТНЬОГО ВЧИТЕЛЯ МУЗИКИ У ЗАКЛАДАХ ВИЩОЇ ОСВІТИ УКРАЇНИ ТА КНР
}

\author{
(C) Цін Шень, 2020 \\ https://orcid.org/0000-0002-7959-9794 \\ http://doi.org/10.34142/2312-2471.2020.63.20
}

У статті розкрито значення загальної культури та ї компоненти. Узагальнено погляди педагогів, мислителів, філософів, учених минулого та сучасності на те, щз учитель повинен володіти високим рівнем духовноморальної культури. Визначено суть духовно-моральноӥ культури під якою розуміють духовний світ людини, систему потреб, орієнтацій, ідеалів, цінностей, загальнолюдських норм які відображають моральну сторону жсттедіяльності людини та духовність ї̈ особистості. Окреслено різні рівні духовної культури особистості: рівень засвоєння загальних духовних изіностей та культури; характер вибору та рівень участі особистості у виробництві духовних иінностей, в освоєнні та споживанні духовних багатств; спрямованість мотивів участі в створенні та споживанні духовних изіностей; рівень освіти, кваліфікації, культури мислення, почуттів та поведінки; створювати умови та спонукати до самовдосконалення. Обгрунтовано залежність духовно-морального виховання иколярів від загальної культури вчителя. Висвітлено вимоги до учителів, які висували відомі у всьому світі педагоги-філософи України та КНР; з'ясовано, щзо у процесі підготовки майбутнього вчителя музики окрім оволодіння ним необхідними професійними знаннями і навичками, особливо важливі ще й рівень його духовної культури та моральний образ. Окреслено коло завдань, щзо допоможе вирішити проблему морально-духовного розвитку особистості учителя: досягнення єдності культури мислення та розумової праці, розвиток духовно-моральні потреби та інтересів, виховання моральної свідомості та культури. Визначено, щуо засобами формування духовно-моральної культури майбутніх учителів музики КНР та України є навчальні дисичпліни, виховна робота закладу освіти, гуртки, факультативи, секції та інше.

Ключові слова: загальна культура, духовно-моральна культура, майбутній вчитель музики.

\section{Tsyn Shen. Formation of Spiritual and Moral Culture of a Future Teacher} of Music in Ukraine and China

The article reveals the importance of general culture and highlights its components. The views of teachers, thinkers, philosophers, scientists of the past and present on a teacher's personality are generalized. The essence of spiritual and moral culture is defined, which means the spiritual world of man, the system of needs, orientations, ideals, values, universal norms that reflect the moral side of human life 
and the spirituality of his/her personality. Different levels of spiritual culture of an individual are outlined: the level of assimilation of general spiritual values and culture; the nature of choice and the level of participation of an individual in the production of spiritual values, in the development and consumption of spiritual riches; orientation of motives of participation in creation and consumption of spiritual values; level of education, qualification, culture of thinking, feelings and behavior; create conditions and encourage self-improvement. It was found that modern schools in Ukraine and in China need a highly cultured, competent, creative music teacher who has the methodology of the pedagogical process. The dependence of spiritual and moral education of schoolchildren on the general culture of a teacher is substantiated. The requirements to teachers put forward by world-famous teachersphilosophers of Ukraine and China are highlighted. It was found that in the process of training a future teacher of music, in addition to mastering the necessary professional knowledge and skills, the level of his/her spiritual culture and moral image are especially important. A range of tasks has been identified that help to solve the problem of moral and spiritual development of a teacher's personality: achieving the unity of the culture of thinking and mental work, development of spiritual and moral needs and interests, education of moral consciousness and culture. It is determined that the means of forming the spiritual and moral culture of a future teacher of music in China and Ukraine are academic disciplines, educational work of educational institutions, clubs, electives, sections and more. music.

Key words: general culture, spiritual and moral culture, future teacher of

Постановка проблеми. Оздоровлення суспільної свідомості та моралі, прищеплення загальнолюдських цінностей, збагачення духовного світу, виховання майбутнього покоління залежать від сформованості духовноморальної культури вчителя. У час активних суспільно-економічних перетворень, культурного та духовного відродження, формування моральної культури у майбутніх педагогів $\epsilon$ необхідною умовою становлення державності.

Аналіз останніх досліджень і публікацій. Аналіз публікацій засвідчує наявність у науково-педагогічній літературі питань щодо формування професійної та загальної культури вчителя (В. Гриньової, А. Донцова, Т.Ткаченко, Т. Сидоренко, Ю.Смаковського, Н.Стрельнікова, І.Шевченко, Чжан Теймин, Ц. Чжао, Лю Цзин та інших). Розвитку особистості вчителя присвячено публікації українських (В. Андрущенко, І. Бех, О. Отич, М.Малахової та інших) та китайських (Тао Сювей, Цзян Сяоянь, Чень Чжаомін, Чжан Лу, Ма Юнцюань та інших) дослідників.

Проблема духовно-моральної культури майбутнього вчителя, як компонента загальної культури, належить до найбільш актуальних у спектрі педагогічних досліджень. Вона була предметом дослідження українських (Т.Дем'янюк, О. Кочерга, О. Кулик, С. Петурня, О. Савчук, Г.Сковорода, В.Сухомлинський, та ін.), інеземних (Л. Ілларіонова, І. Ільїн, Б. Вульфов, К.Атрамонова, Г. Щербіна, Л. Шевченко та ін.) та китайських (Конфуцій, Чжан 
Бо-дуань, Жень Хуа, Чэн Чжун-ин, Чжао Цинь та ін. ) педагогів, мислителів, філософів, учених минулого та сучасності.

Виділення невирішених раніше частин загальної проблеми. Більшість дослідників наголошує на значущості духовно-моральної культури для майбутнього учителя, на особливості ऑï змісту для кожної нації. Водночас, порушена проблема свідчить, що у китайській та українській педагогічній думці вона досліджена недостатньо.

Мета роботи - розкрити сутність духовно-моральної культури та засоби іiі формування у майбутнього вчителя музики в закладах вищої освіти України та KHP.

Виклад основного матеріалу. Не зважаючи на стрімке реформування системи освіти та зміни, що відбуваються у змісті освіті, традиційним та незмінним у більшості країн залишається підхід до формування загальної культури майбутнього вчителя. Компонентами якої $\epsilon$ такі складники: екологічна, естетична, моральна, комунікативна, духовна, моральна та ін.

Під духовно-моральною культурою слід розуміти духовний світ людини, систему потреб, орієнтацій, ідеалів, цінностей, загальнолюдських норм, які відображають моральну сторону життєдіяльності людини та духовність іiі особистості [4].

Педагог, у якого сформована загальна культура здатний до високих духовних станів, вміє встановлювати тонкі духовні зв’язки між людьми, виявляючи при цьому турботу, чуйність, повагу, переживання, толерантність, емпатію [1].

3 іншого боку, даний вид культури проявляється у ставленні до себе, до інших людей, суспільства та держави; у виборі підходів та принципів до виховання майбутнього покоління [7].

У процесі аналізу науково-педагогічних досліджень ми з’ясували, що у поняття «духовно-моральна культура» як українські, так і китайські педагоги вкладають подібний зміст.

Тобто духовно-моральна культура майбутнього вчителя музики, проявляється у процесі добросовісного виконання професійних обов'язків, виявленні справедливості до учнів, колег та оточення, демонстрації емоційної щирості, прояві відповідальності та інше.

Тільки той вчитель, який володіє духовною культурою, може самостійно створити духовну атмосферу для своїх учнів. А духовністю учителя є «...життя за законами Істини, Добра, та Краси, що створює гармонійне існування людини зі світом...» [5]. Учитель, який володіє духовністю, з легкістю долає професійні та соціальні труднощі; виявляє справжню любов до дітей, виконує свій моральний обов'язок.

Ще у давній Греції виникли певні стандарти (шаблони) того, яким має бути вчитель: чітко викладати навчальний матеріал, уміти контролювати свою поведінку, бути справедливим та інші. Усі ці характеристики не втратили актуальності й сьогодні.

Для педагогів багатьох поколінь в усьому світі надзвичайно цінною $є$ повчання високодуховного мислителя, філософа та педагога Григорія Савича 
Сковороди [9]. Він вважав, що учителем може бути людина, яка відчуває справжнє покликання до своєї професії. Філософ порівнював педагога 3 дбайливим садівником та зазначав, що тільки професійна, схильна до постійного саморозвитку та самовдосконалення, вихована людина, яка опанувала духовно-моральні цінності, зможе стати справжнім учителем.

Особливу роль Г.С.Сковорода [9] надавав музичному вихованню майбутніх поколінь, адже був переконаний, що музика допомагає осягнути світ.

У КНР особливо цінують духовно-культурну спадщину, яку залишив по собі стародавній китайський мислитель, філософ, педагог та політик Конфуцій. Він заснував перший університет, бо вважав, що освіта відіграє провідну роль в еволюції суспільства. Філософ особливо переймався питаннями етики та моралі, був переконаний, що загальнолюдські цінності мають бути понад усе. Пропагував свої ідеї та погляди учням. Присвятив ряд книг даній проблемі: «Записки про правила благопристойності», «Книга установлень», «Трактат про правила поведінки», «Записки про норми поведінки».

Конфуцій окреслив власні критерії моральності та обов'язки людини, наголошував на вихованні гуманності, стверджував, що людина може самовдосконалюватись лише шляхом духовного очищення. Зі своїми учнями вивчав шість мистецтв, серед яких особливе місце посідала музика [10]. Музика має потужний емоційний вплив на внутрішні почуття та переживання людини, впливає на іiі духовність, стимулює до морального виховання та вдосконалення особистісних якостей, формує моральні та естетичні ідеали.

На нашу думку, тільки вивчаючи спадщину митців духовно-морального виховання минулого, учителі музики зможуть транслювати загальну культуру учням у майбутньому.

Ми з'ясували, що духовна культура особистості може мати кілька рівнів, серед яких:

- рівень засвоєння загальних духовних цінностей та культури;

- характер вибору та рівень участі особистості у виробництві духовних цінностей, в освоєнні та споживанні духовних багатств;

- спрямованість мотивів участі в створенні та споживанні духовних цінностей;

- рівень освіти, кваліфікації, культури мислення, почуттів та поведінки [2].

Як в Україні, так і в КНР, процес підготовки майбутнього педагога передбачає не лише оволодіння ним необхідними професійними знаннями $і$ навичками, а й високим рівнем духовної культури, формування морального образу.

На освіту та розвиток учнів впливає багато факторів, але особистісний $\epsilon$ найвагоміший. Саме від особистості педагога буде залежати виховання дітей. Особливо це стосується майбутніх учителів музики, адже саме на них покладена роль не лише носіїв, а й творців культури. 
Духовно-моральне виховання в Україні переживає системну кризу [12], як результат люди втрачають загальнолюдські цінності, порушують прийняті норми поведінки, руйнують той фундамент духовності, який будувався віками.

Відмінним для КНР є те, що морально-духовне виховання відбувається паралельно та узгоджено 3 економічним розвитком у країні [3]. На сьогоднішній день модернізація сучасного суспільства у КНР постійно супроводжується трансформацією його духовно-моральних цінностей.

Не зважаючи на різний стан духовно-морального виховання в Україні та КНР, обидві країни потребують висококультурного, компетентного, творчого вчителя музики, який володіє методологією педагогічного процесу.

Підготовка майбутнього вчителя музики як в Україні, так і в КНР передбачає оволодіння педагогом загальною культурою та професійними компетентностями. У процесі навчання він опанує загальноприйняті вироблені століттями норми та правила педагогічної діяльності. Майбутній педагог, здобуваючи нові знання, визначаючи цінності, збагачуючи свій духовноморальний та інтелектуальний потенціал, формує своє особисте ставлення, самовизначається у своїх поглядах. У майбутньому це допоможе мобільно реагувати у складних соціокультурних реаліях. Ключове завдання закладів освіти полягає у тому, щоб створити якісне освітнє середовище для здійснення відповідної підготовки майбутніх педагогів-музикантів.

Ми глибоко переконані, що у процесі підготовки майбутніх учителів музики вкрай необхідно створити умови для взаємопроникнення та взаємозбагачення різних культур, це сприятиме формуванню їх духовноморальної культури. Лише таким чином майбутні педагоги-музиканти зможуть пройнятись культурами інших країн, навчаться їх поважати, будуть більш шанобливо ставитись до національної культурної спадщини, вчитимуть цьому своїх учнів.

Важливо сформувати готовність майбутнього педагога-музиканта до збагачення духовного світу школярів пізнаючи досвід минулих поколінь; навчання розумінню, повазі до культурних надбань людства, транслювання краси та культури у спілкуванні, роботі, навчанні упродовж усього життя; розвитку у школярів творчих здібностей [8].

Чжу Цзюньцяо наголошує на тому, що саме через уроки музичного мистецтва вчитель впливає на духовне становлення учнів, а музика $є$ основним порталом до духовно-морального виховання учнів [11].

До концепції формування у майбутніх педагогів духовно-моральної культури можна віднести наступні положення:

- вплив соціального середовища;

- організація навчальної та позанавчальної діяльності;

- комунікативний компонент [13].

Формування духовно-моральної культури майбутнього педагога слід розглядати як синтез чотирьох аспектів ціннісно-світоглядного, змістовнотехнологічного, креативно-творчого, критеріально-оцінювального. При забезпеченні організаційно-управлінських, змістовно-технологічних, 
організаційно-педагогічних та духовно моральних умов навчання процес формування зазначеної культури буде ефективним [13].

Одним із напрямів вирішення проблеми морально-духовного розвитку особистості майбутнього вчителя є виконання певних завдань:

- досягнення єдності культури мислення та розумової праці;

- $\quad$ розвиток духовно-моральні потреби та інтереси;

- виховання моральної свідомості та культури;

- створення умов та спонукання до самовдосконалення.

Узагальнюючи положення, умови та засоби формування духовноморальної культури майбутнього педагога запропоновані дослідниками, можна зробити висновок, що ключовим фактором, від якого буде залежати сформованість зазначеної культури $\epsilon$ освітнє середовище закладу освіти. Виключно від того, як воно буде організоване, відбуватиметься вплив на загальнокультурний розвиток майбутнього учителя.

Духовно-моральна культура майбутніх учителів музики формується у процесі вивчення навчальних дисциплін та у позанавчальний час. Щодо навчальної програми маємо констатувати той факт, що в українських закладах вищої освіти переважна більшість загальноосвітніх дисциплін («Культурологія», «Екологія», «Етика», «Естетика» «Політологія» та багато інших), які мають вагомий вплив на формування духовно-моральної культури майбутніх педагогів, за останні роки зведено до мінімуму та перетворено на короткотривалі інтегровані курси.

В КНР такі загальноосвітні дисципліни як «Ідейно-моральне виховання», «Політологія», «Соціологія» та багато інших $є$ обов'язковими, грунтовними, тривалими, студенти складають за ними іспити.

Оновлена система підготовки майбутніх учителів музики в навчальних закладах КНР має ряд переваг, серед яких зміна змісту програми підготовки майбутніх педагогів, оновлення підручників, використання окремих методів навчання. Однак, найсуттєвішим досягненням, на нашу думку, є гуманістична направленість на реалізацію виховних цілей у країні у цілому, реалізація концепції «людино-орієнтованості освіти» [6].

Спільним для обох країн $є$ те, що виховна робота закладів вищої освіти України та КНР, що готують майбутніх педагогів-музикантів, недостатньо націлена на формування саме духовно-моральної культури студентів. Тому виникає потреба у пошуку нових технологій виховання, зміні змісту виховної роботи.

Важливим для закладів вищої освіти обох країн $є$ повернення актуальності гуртків, секцій, факультативів та інших видів позааудиторної діяльності.

У КНР, на відміну від України, проблема формування духовно-моральної культури у майбутніх учителів музики стоїть не так гостро. Це зумовлено постійним зверненням до історичної культурної спадщини китайського народу; направленістю на духовно-моральне виховання у країні в цілому; відмінностями у змісті підготовки майбутніх педагогів. 
Висновки. Духовно-моральна культура $\epsilon$ невід'ємною складовою загальної культури вчителя музики. У ході дослідження ми встановили, що для України та КНР спільним є розуміння iï суті, що проявляється у оволодінні загальнолюдськими культурними цінностями, нормами поведінки, моралі та їх транслюванні. Враховуючи те, що даний вид культури $є$ необхідним для здійснення педагогічної діяльності, слід скорегувати засоби його формування у навчальному та позанавчальному процесі.

До освітніх програм українських та китайських закладів вищої освіти, які готують учителів музики, повинна бути включена дисципліна «Духовноморальна культура» (або представлена, як дисципліна за вибором); необхідно ввести зміни щодо змісту позанавчальної діяльності у відповідних закладах вищої освіти України та КНР.

Перспектива подальших досліджень. 3 метою вирішення окресленої проблеми предметом наших подальших дослідження $\epsilon$ розробка та впровадження методичного комплексу щодо формування духовно-моральної культури майбутнього вчителя музики у закладах вищої освіти України та КНР.

\section{Лimepamypa}

1. Белякова О.С. Загальнокультурна підготовка майбутніх вчителів в освітньому процесі педагогічних університетів. автореф. дис. ... канд. пед. наук: 13.00.04. Харків. 2015. 20 с.

2. Донцов А. Моральна культура вчителя. Монографія. Х.: ХНУ імені В.Н.Каразина, 2008. 240 с.

3. Дунцзянь Цзяо. Народные традиции Китая в ситуации модернизации общества; автореф. дис... канд. культур. наук: 24.00.01. М., 2001. 24 с.

4. Илларионова Л.П. Фомирование духовно-нравственной культуры учителя в системе непрерывного педагогического образования. Сибирский педагогический журнал. 2005. №2. С. 53-71.

5. Кучерова О.С. Духовно-нравственная культура учителя в контексте современности. Научные ведомости БелГУ. Сер. Гуманитарные науки. 2014. №20(191), вып.23. С. 189-195.

6. Лю Цзин. Преимущества новой системы подготовки учителей музыки в учебных заведениях КНР по специальности «Музыкальное образование». Искусство и культура 2017. № 4(28). С. 91-96.

7. Петлява В.В. Педагогічні умови формування моральної культури майбутнього вчителя іноземних мов. Дис. канд. пед наук:13.00.04, 2019, 261 с.

8. Процюк В. Культурологічні аспекти підготовки майбутнього вчителя музики. Актуальні питання гуманітарних наук. 2015. № 12. С.124-129.

9. Сковорода Г. Твори: в 2 т. / Український науковий інститут Гарвардського університету, Ін-т літератури імені Т.Г. Шевченка НАН України. К.: Обереги, 1994. Т. 1.527 с.

10. Чжен В. Модернізаційний потенціал конфуціанства на етапі “політики реформ і відкритості”: Можливості та реалії. Краєзнавчі дослідження. 2017. № 1-2. C.22-33. 
11. Чжу Цзюньцяо. Особливості формування музичної культури школярів засобами вокального виконавства. Вісник ЛНУ імені Тараса Шевченка 2013. №18 (277), Ч. II, С. 206-213.

12. Шевченко Ю., Абламонова В. Духовно-моральні цінності як основа морального виховання молодших школярів. Педагогічні науки: теорія, історія, інновачійні технологіï. 2015. № 7(51). С 476-485.

13. Щербина А. Формирование духовно-нравственной культуры будущих педагогов дошкольных образовательных учереждений. автореф. дис... канд. пед. наук: 13.00.08. Москва, 2013. 26.c.

\section{References}

1. Belyakova, O.S. (2015). Zagal nokul turna pidgotovka majbutnix vchy`teliv v osvitn`omu procesi pedagogichny`x universy`tetiv [General cultural training of future teachers in the educational process of pedagogical universities]. (PhD's Thesis). Kharkiv.(in Ukrainain).

2. Doncov, A. (2008). Moralna kultura vchitelya Moralna kultura vchitelya [Moral culture of a teacher]. Kh.: KhNU imeni V.N. Karazina. (in Ukrainain).

3. Dunczyan Czyao. (2001). Narodnye tradicii Kitaya v situacii modernizacii obshestva [Folk traditions in China in a situation of modernization of society]. (PhD's Thesis). M. (in Russian).

4. Illarionova, L.P. (2005). Fomirovanie duhovno-nravstvennoj kultury uchitelya $\mathrm{v}$ sisteme nepreryvnogo pedagogicheskogo obrazovaniya [Formation of the spiritual and moral culture of a teacher in the system of continuous pedagogical education]. Sibirskij pedagogicheskij zhurnal, 2, 53-71. (in Russian).

5. Kucherova, O.Ye. (2014). Duhovno-nravstvennaya kultura uchitelya v kontekste sovremennosti [Spiritual and moral culture of a teacher in the context of modernity]. Nauchnye vedomosti BelGU. Ser. Gumanitarnye nauki, 20(191), Vyp. 23, 189-195. (in Russian).

6. Lyu Czin (2017). Preimushestva novoj sistemy podgotovki uchitelej muzyki v uchebnyh zavedeniyah KNR po specialnosti «Muzykalnoe obrazovanie» [Advantages of the new system of training music teachers in educational institutions of the PRC in the specialty "Music Education"]. Iskustvo i kultura, 4(28), 91-96. (in Ukrainain).

7. Petlyava, V.V. (2019). Pedagogichni umovy` formuvannya moral'noyi kul tury` majbutn`ogo vchy`telya inozemny`x mov [Pedagogical conditions of moral culture formation of a future teacher of foreign languages]. (PhD's Thesis). (in Ukrainain).

8. Procyuk, V. (2015). Kul`turologichni aspekty` pidgotovky` majbutn`ogo vchy`telya muzy`ky` [Cultural aspects of training a future music teacher]. Aktual`ni py`annya gumanitarny`x nauk, 12, 124-129. (in Ukrainain).

9. Skovoroda, H. (1994). Tvory: v 2 t.[Works: in 2 volumes] (Vol. 1). K.: Oberehy. (in Ukrainain).

10. Chzhen, V. (2017). Modernizacijnij potencial konfucianstvana etapi "politiki reform i vidkritosti": Mozhlivosti ta realiyi [Confucian modernization 
potential at the stage of "policy of reform and openness": Opportunities and realities]. Krayeznavchi doslidzhennya, 1-2, 22-33. (in Ukrainain).

11. Chzhu Tsziuntsiao (2013). Osoblyvosti formuvannia muychnoi kultury shkoliariv zasobamy vokalnoho vykonavstva [Formation features of musical culture of schoolchildren by means of vocal performance]. Visnyk LNU imeni Tarasa Shevchenka, 18(277), 206-213. (in Ukrainain).

12. Shevchenko, Yu., \& Ablamonova V. (2015). Duxovno-moral'ni cinnosti yak osnova moral`nogo vy`xovannya molodshy`x shkolyariv [Spiritual and moral values as a basis of moral education of junior pupils] Pedagogichni nauky: teoriya, istoriya, innovacijni texnologiyi, 7(51), 476-485. (in Ukrainain).

13. Sherbina, A. (2013). Formirovanie duhovno-nravstvennoj kultury budushih pedagogov doshkolnyh obrazovatelnyh ucherezhdenij [Formation of spiritual and moral culture of future teachers of preschool educational institutions]. (PhD's Thesis). Moscow. (in Russian). 